\title{
The Concept of Academic Excellence: A Macro Analysis
}

\author{
Prof. Nabeel A. Jurdi Ph.D. \\ President, Emirates College for Management and Information Technology, United Arab Emirates \\ Ms. Fadia Moosa Rasheed...BA, MA, ABD \\ United Arab Emirates \\ Dr. Radhakrishnan \\ Director of Research, Emirates College for Management and Information Technology, United Arab Emirates
}

\begin{abstract}
In the increasingly competitive, globalized economy and emergence of new business models, effective and efficient management is vital for any organization offering products and/or services. This highlights the significance of management and the pivotal role of academic excellence as a catalyst in shaping the future learners to serve organizations better. In the contemporary world, Governance, Leadership, strategic planning, performance and quality management, innovation in teaching- learning, research and consulting play a vital role towards academic excellence . Based on the Global perspectives, critical elements for academic excellence are identified in addition to the risks involved
\end{abstract}

Keywords: Academic Excellence, Strategic performance, Quality, Learning outcomes

DOI: $10.7176 / \mathrm{JLPG} / 81-08$

\section{Introductions}

Academic excellence determines the competitiveness of an Institution in the contemporary market place and is the driving force to reckon with, in making the Institution to contemplate more along quality levels of program for gaining competitive advantage. The crucial Knowledge, Comprehension, Application, Analysis, Synthesis and Evaluation define the different key levels of Learning. Program design, delivery, Assessments should be aligned to contribute towards the achievement of these different key levels of learning to contribute to excellence in education. To be able to compete with the leading universities of the world Institutions should focus on the following reasons lying behind the academic excellence project

- World's leading countries are competing very tough to gain superiority in trade, Industry, science and technology.

- Nations who will stay behind in this race will be dominated by the winners.

- Therefore the national richness, security and civilization will be in jeopardy in the future If quality in higher education is not secured at higher education.

- The only way to avert this challenge is excellence in academic endeavors.

\section{Methodology}

The pivotal areas to be focused for transition towards excellence in Higher Education are outlined as follows:

\subsection{Governance System for Strategic Planning}

The establishment of effective governance in higher education institutions is essential to periodically assess the effectiveness of governance system with respect to strategic objectives of Integrity, Accountability and Credibility. This requires establishing an effective Board of Governors with members from different areas of expertise to guide the mission and vision of the institution with significant contribution. This Board of Governors should include persons with entrepreneurial drive and acumen for quality to direct the institution towards educational excellence. They should have very good networking with the external stakeholders for complementing the institutional development. The Governing Board must understand how to make optimal decisions from among a number of alternatives.. It is even more important to understand how not to make suboptimal decisions.

Strategy formulation should consider risk management and the effective use of institutional resources to steer the organization in the right direction. They should also take into consideration the emerging trends and developments in the education field and understand the impact of globalization and technology on the future of higher education in Universities. Higher education institutions must develop a common Institution wide strategic framework to operate and achieves its ambitions. Also there should be mechanism to assesses and manages risks in four broad sectors:

- $\quad$ Financial viability

- IT infrastructure 
- $\quad$ Facilities (including Machinery and documentation)

- Health and Hazards

\subsection{High Performance and Quality Enhancement}

In today's world, quality is a vital determinant of organizational excellence and providing high quality products and services to customers is no longer a differentiator, but a necessity. Organizations have recognized the need for designing and implementing effective systems for ongoing monitoring of, and reporting on, program quality. As competition intensifies, it is imperative that a comprehensive assessment framework in quality management needs to be adopted on a continual basis. Institutions though effectively planning should strive to continually assess academic quality through evidence-based assessment, while being responsive towards future requirements for external assessment and accreditation..

Quality tools and techniques for continuous improvement are widely adopted nowadays to foster academic excellence in higher education. Development of Learning Analytics Framework for Assessing Academic Excellence) can help higher educational institutions in the development and deployment of effective systems to support quality and continuous improvement

\subsection{Innovation in teaching and learning. Process}

In the 21 st Century digital era, digital revolution is having a pivotal position in the education arena. The younger generation learners are "tech-savvy", who are seeking quality, engaging and affordable ways of learning. It is worthwhile to move towards smart class room model for sustaining excellence and innovation in teaching and learning and to deliver quality education.

\subsubsection{New Priorities In Higher Education}

Instead of giving priority to increasing the abilities of literacy and mathematics...... Giving priority to Comprehension, analysis, problem solving, Creativity and drawing conclusions

\subsubsection{Anticipated Outcome}

To give necessary skills and power to the graduates which will enable them to grasp an opportunity in the international market?

End result: Restructuring the education and preparing the students to the new global living Conditions...

The application model highlighting RIGOR and RELEVANCE for quality assurance

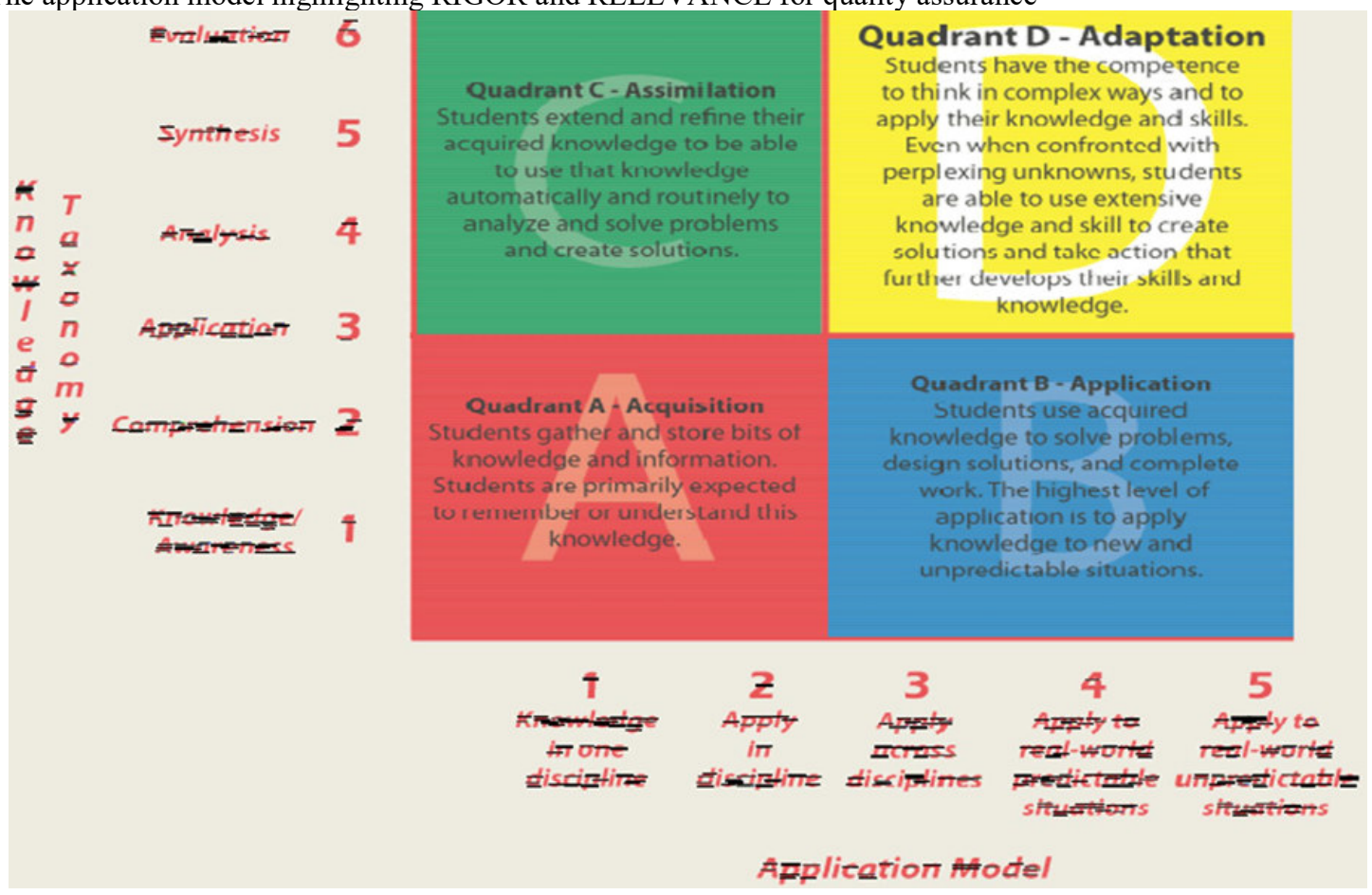

Figure 1. The Trend of Economic Development

Description for the above figure.

Efficient quality management is a complex process which entails the contribution of the various assessment components towards achievement of desired Learning Outcomes in terms of Knowledge, Comprehension, Application, Analysis, Synthesis and Evaluation.. The course quality decides the achievement of program 
objectives and outcomes. The combination of various courses leads to Program quality which can be measured to reinforce if it has achieved the different key levels of learning. The combination of various programs leads to Institutional quality which can be measured based on the levels of quality achieved in different programs of study.

Recently, there is an increasing level of interest in learning analytics and generally deals with the development of methods that harness vast educational data sets to support the learning process. Institutions should develop appropriate mechanisms like Learning analytics Model to measure the Quality in terms of achievement of Course Learning Outcomes(CLOs) achieved for courses as well as in terms of key levels of learning outcomes achieved for the program(PLOs).

\subsection{Creative Research for knowledge base}

The scope of creative research will include acquiring new knowledge and utilizing it in innovative applications and/or contribution to the knowledge-base. This research and development strategy is expected to be pursued in alignment with the Institution's mission and goals.

With the emergence of the knowledge-based economy, current priorities of higher education should be aimed at supporting the social-economic development of nations though sufficient research work to strengthen their knowledge base. Research policy should ensure faculty and student engagement in research and scholarly activities and also make adequate provisions to support and encourage such engagement. The Research initiative should be in alignment with the stipulated Research Strategic Plan. Furthermore, institutions are encouraged to align their research activities towards the betterment of the society's overall needs. Research strategy in the Institution should focus on individual, interdisciplinary and multidisciplinary areas. The ultimate objective of this strategy is to enhance research in selected areas to enhance faculty members' knowledge to keep the faculty in forefront of knowledge through scholarship and research and in turn to compliment students learning.

\subsection{Applied Consultancy for Competency base}

The major objective of the Consulting is to solve complex business problems and to improve organizational performance. This is a transition from knowledge base to skill and competency base. Making available competency base by way of training and consulting to Government and industries for better performance in terms of quality, efficiency and effectiveness and the role of higher education Institutions and its contribution in this regard is immense towards serving the society better. A key strategy for the achievement of academic excellence is to address national needs and to conduct research and consultancy with an adequate emphasis on business applications in collaboration with stack holders of society and government. Faculty should develop necessary skills to conduct a rapid and effective assessment of a given business situation to propose appropriate solutions subject to organizational constraints. They will develop competencies in the practical application to provide creative solutions and for this purpose will acquire competency in applying tools, concepts and methodologies.

To be successful consultants in the competitive consulting industry, faculty should focus on the key success factors for a sustainable and responsible consulting practice which involves the following major tasks :

- $\quad$ Problem setting

- $\quad$ Idea generation and problem solving

- $\quad$ Data and Information acquisition

- Generating the best solution and Designing an Action Plan

- Solution presentation and discussion

To enhance consulting expertise, Faculty should learn how to combine concepts and models of analysis on different levels to enhance their understanding of organizational phenomena. They will develop an understanding of the most important managerial approaches towards motivating employees, managing groups and teams, and analyzing work organization.

\subsection{Global Outlook}

The following criteria highlight the global outlook in the right perspectives

- $\quad$ Creating global citizens thru training,

- Increasing the level of conscientiousness of the students on the career needs in the future,

- $\quad$ Training students with vocational skills to be needed in the future,

- $\quad$ Helping students understanding other cultures,

- $\quad$ Empowering students with the skills of forecasting and observing the theoretical and

Practical developments in their prospective careers

- $\quad$ Increasing the number of academicians with international experience.

- $\quad$ Establishing a global academic climate

- $\quad$ Encouraging all Faculties to participate actively in Research. 
Providing financial supports to those academicians planning to participate in international Scientific activities and presenting paper.

Branding the Institution as a prestigious Local \& Regional College/ university

\subsubsection{Global Outlook-An Example}

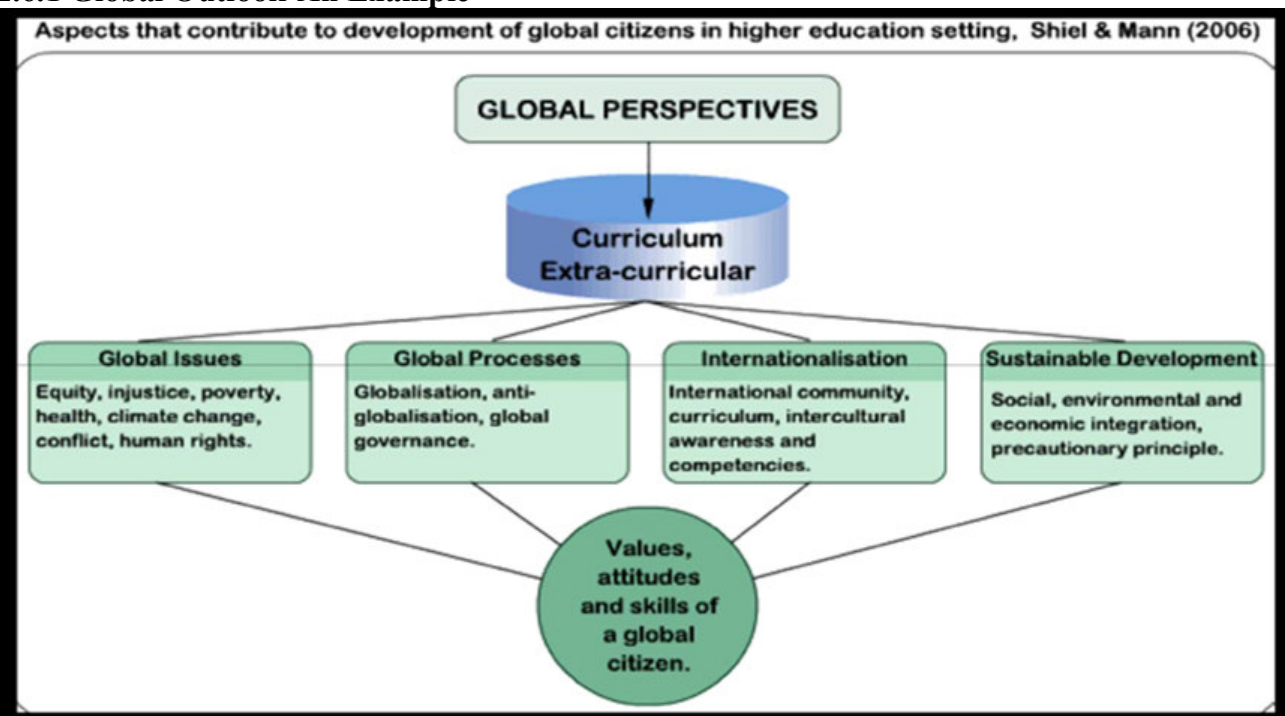

2.6.2 Basic Strategies

* $\quad$ Giving priority to extremely important but neglected scientific areas

* Adopting sustainable development as a common learning objectives for all courses

2.6.3 Risks Involved

- $\quad$ Global village: Lots of competing nations with a strong will to win the race for Superiority in technology.

- Radical changes in global markets:

- Changing structure of global working technological and economic competition.

- Some countries already began to lead in the race and gap between them and others is Widening.

- New raw materials: knowledge, learning, innovation, information and skillful.

\subsubsection{Indicators}

International comparisons

Statistical data: ranking universities

Quality of training

Number of scientific publications

Requests and demands coming from business circles

2.6.5 Critical Elements In Excellence

The following highlights the critical elements to be focused towards academic excellence 


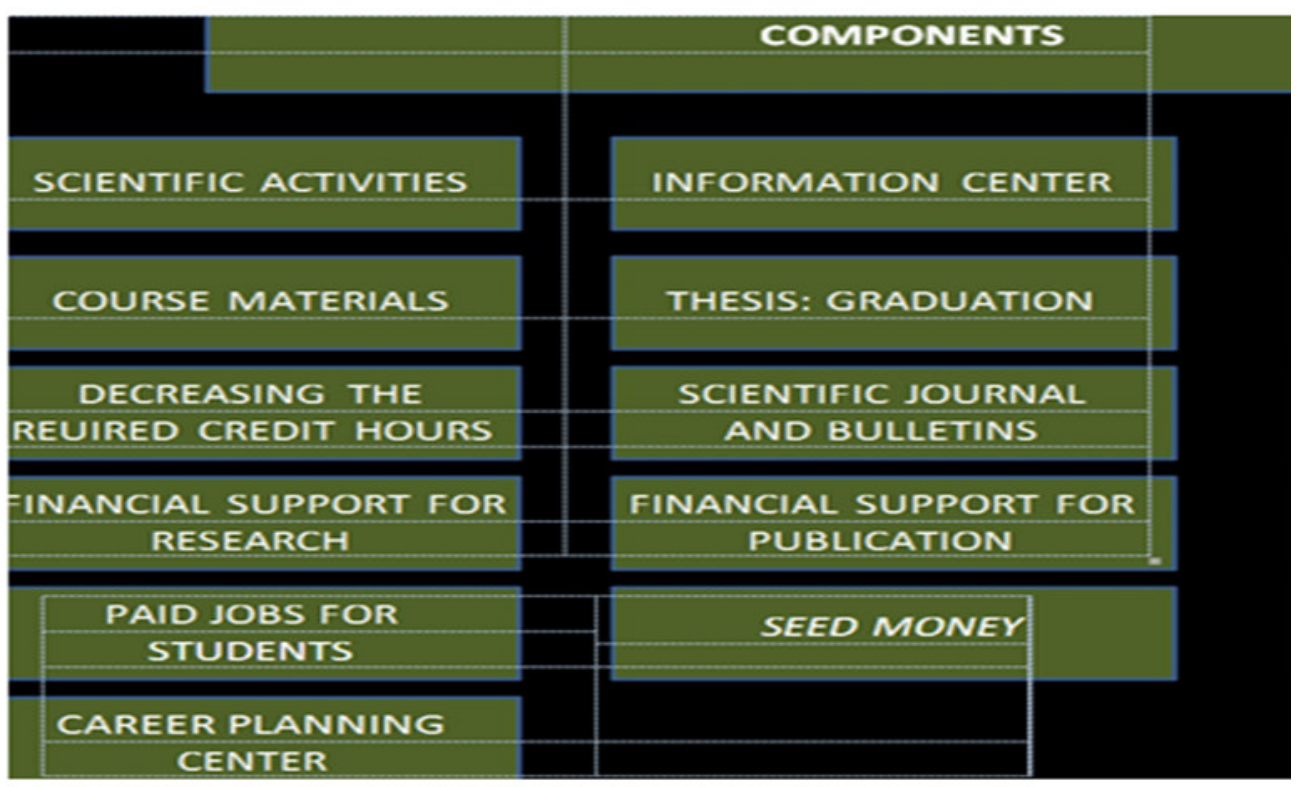

\begin{tabular}{|c|c|c|}
\hline $\begin{array}{l}\text { GLOBAL ACADEMIC } \\
\text { INTEGRATION }\end{array}$ & $\begin{array}{l}\text { INCREASING ACADEMIC } \\
\text { PERFORMANCE }\end{array}$ & $\begin{array}{l}\text { BALANCE BETWEEN } \\
\text { KNOWLEDGE GENERATION } \\
\text { AND DIFFUSION }\end{array}$ \\
\hline $\begin{array}{l}\text { INSTITUTIONAL } \\
\text { INTEGRATION AND } \\
\text { RESTRUCTURING }\end{array}$ & DISTANCE LEARNING & $\begin{array}{l}\text { UNIVERSITY BUSINESS } \\
\text { COOPERATION }\end{array}$ \\
\hline $\begin{array}{l}\text { DEVELOPING AND } \\
\text { EASSESING THE } \\
\text { NATIONAL POLICIES }\end{array}$ & $\begin{array}{l}\text { INCREASING THE } \\
\text { NUMBER OF FOREIGN } \\
\text { STUDENTS }\end{array}$ & $\begin{array}{l}\text { POLICY AND INSTITUTION } \\
\text { FOR PUBLICATIONS }\end{array}$ \\
\hline $\begin{array}{l}\text { DEVELOPING NEW } \\
\text { CRITERIA FOR } \\
\text { ACADEMIC FREEDOM }\end{array}$ & $\begin{array}{c}\text { CRITERIOA OF ACADEMIC } \\
\text { AUTONOMY }\end{array}$ & $\begin{array}{c}\text { ACADEMICAL } \\
\text { PERFORMANCE } \\
\text { MANAGEMENT SYSTEM }\end{array}$ \\
\hline $\begin{array}{l}\text { DEVELOPING ACADEMIC } \\
\text { QUALITY STANDARDS }\end{array}$ & $\begin{array}{l}\text { PUBLICATION QUALITY } \\
\text { AND PERFORMANS }\end{array}$ & $\begin{array}{l}\text { RELATIONS BETWEEN } \\
\text { THE UNIVERSITY AND } \\
\text { THE SOCIETY }\end{array}$ \\
\hline $\begin{array}{l}\text { STUDENT LIFE IN THE } \\
\text { CAMPUS }\end{array}$ & $\begin{array}{l}\text { NATIONAL AND INTERNATIONAL } \\
\text { PROMOTION THE UNIVERSITY }\end{array}$ & $\begin{array}{c}\text { STRUCTRUAL } \\
\text { DEFICIENCIES AND } \\
\text { MISTAKES }\end{array}$ \\
\hline
\end{tabular}

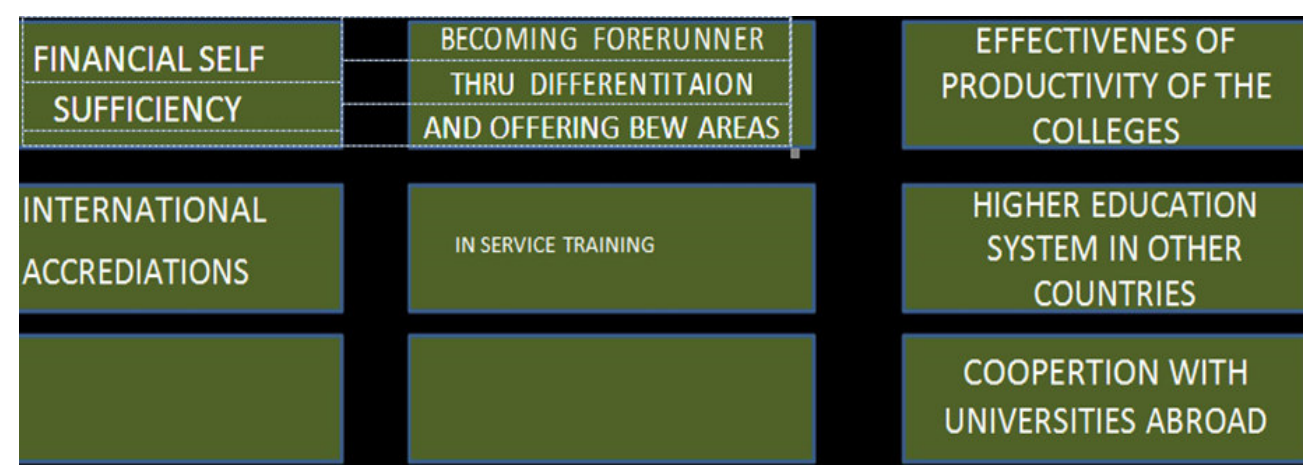

\subsection{Conclusion}

In this paper, a macro analysis of key factors to be focused by institutions of higher learning for academic 
excellence is proposed highlighting the pivotal role of Governance, Leadership, strategic planning, performance and quality management, innovation in teaching- learning, research and consulting. Global perspectives towards academic excellence is discussed, critical elements for academic excellence are identified in addition to the risks involved. In this global competitive era, the Higher education Institutions should prioritize accordingly and also have commitment to develop learning analytics models for quality assurance to stay in the forefront of academic excellence.

\section{References}

Astin, A. (1985.),Achieving Educational Excellence: A Critical Analysis of Priorities and Practices in Higher Education, Jossey-Bass, San Francisco.

Clanchy, J. and B. Ballard. (1995), Generic Skills in the Context of Higher Education', Higher Education Research and Development, Vol. 14(2), Routledge, London.

Coates, H. and A. Radloff (.2008),.Tertiary Engineering Capability Assessment: Concept Design, Australian Council for Educational Research (ACER), Camber well.

Douglass, J. et al. (2012), The Learning Outcomes Race: the Value of Self-Reported Gains in Large Research Universities, Higher Education, Vol. 64, pp. 317-335

E. Canth-Paz. (1995). A summary of research on parallel genetic algorithms, Illinois Genetic Algorithms Lab., Univ. Illinois at Urbana-Champaign.

OECD 2007. Assessing Higher Education Learning Outcomes', OECD, Paris.

OECD 2008. 'Measuring Improvements in Learning Outcomes', OECD Publishing, Paris

Radhakrishnan \& Jeyanthi,,2018. 'Measurement of learning outcomes for Quality Assurance: A systematic approach', International Education and Research Journal, Vol 4, Issue 11,pp 32-33 